\title{
Pemeriksaan Cemaran Kapang Pada Udara dan Pakaian Santri di Salah Satu Pondok Pesantren Surabaya Timur
}

\author{
Anindita Riesti Retno Arimurti1, Fitrotin Azizah1, Amru Rohman Maulana1, \\ Achmad Machrus ${ }^{1}$
}

\author{
Prodi DII Analis Kesehatan, FIK, Universitas Muhammadiyah Surabaya
}

\begin{abstract}
Dormitory is a place for student who built in various small scales to a very large scale. Of the many dormitory residents with bad space such as lack of ventilation and incoming sunlight, the large number of scattered students' clothes causes the room to become damp. The presence of air mold is caused by the lack of ventilation as well as the humidity of the room environment in the dormitory which can cause several diseases, one of which is ARI. The purpose of this study was to determine whether or not there is mold contamination on air in the room and clothes of the students at one of the Islamic boarding schools in East Surabaya. This type of research is descriptive. The sample used is air in several dormitory rooms at one of the Islamic boarding schools in East Surabaya. This research method uses the isolation technique of Sabauraud Dextose Agar (SDA) media which is partially opened and then placed in several rooms in this Islamic boarding school. Second, 30 samples of clothes were taken randomly from students from different disciplines and then scratched on SDA media. In the results of macroscopic observations, of the 30 sampled rooms. Microscopic colonies of cotton taken from the media showed positive results for hyphae, mycellium, spores, and conidiospores. The results obtained were positive there were Aspergillus sp. with the percentage was $100 \%$ while the results of the students' clothing swabs, from 30 clothing samples found $80 \%$ positive for mold contamination.
\end{abstract}

Keywords: Air mold; Clothing; Islamic Boarding Schools; Mold

\begin{abstract}
Abstrak
Asrama adalah tempat hunian bersama untuk pelajar skala kecil hingga skala sangat besar. Dari banyaknya penghuni asrama dengan ruang yang tidak baik seperti minimnya ventilasi dan sinar matahari yang masuk, pakaian santri yang berserakan menyebabkan ruangan menjadi lembab yang dapat menimbulkan penyakit misalnya penyakit ISPA. Tujuan penelitian ini untuk mengetahui ada tidaknya cemaran kapang pada udara yang ada pada ruangan dan pakaian santri di salah satu Pondok Pesantren di Surabaya Timur. Jenis penelitian yang digunakan adalah deskriptif. Sampel yang digunakan adalah udara di beberapa ruang asrama salah satu Pondok Pesantren di Surabaya Timur. Metode penelitian ini menggunakan teknik isolasi, media Sabauraud Dextose Agar (SDA) dibuka sebagian kemudian ditaruh pada beberapa ruangan di Pondok Pesantren ini. Yang kedua, sampel baju sejumlah 30 yang diambil secara acak dari santri yang berbeda-beda diswab kemudian digoreskan pada media SDA. Pada hasil pengamatan makroskopis, dari 30 ruangan yang disampling, terdapat kapas atau bludru menandakan adanya pertumbuhan Kapang. Pada mikroskopis Koloni kapas diambil dari media, didapatkan hasil positif adanya hifa, misellium, spora, konidiospora. Hasil yang didapatkan positif terdapat Kapang Aspergillus sp. dengan persentase 100\% sedangkan hasil swab pakaian santri, dari 30 sampel pakaian ditemukan 80\% positif kontaminasi kapang.
\end{abstract}

Kata kunci: Kapang; Kapang Udara; Pakaian; Pondok Pesantren

\footnotetext{
${ }^{1}$ Corresponding Author: Anindita Riesti Retno Arimurti, email: aninditariesti@fik.um-surabaya.ac.id, Prodi DII Analis Kesehatan, FIK, Universitas Muhammadiyah Surabaya
} 


\section{Pendahuluan}

Infeksi Saluran Pernapasan Akut (ISPA) adalah penyakit yang disebabkan oleh infeksi jasad renik atau bakteri, jamur, dan virus. Apabila dibandingkan dengan kelompok penyakit lainnya, ISPA merupakan suatu kelompok penyakit sebagai penyebab angka absensi tertinggi. Penyakit ISPA sering terjadi pada anak-anak, hal tersebut diketahui dari hasil pengamatan epidemiologi bahwa angka kesakitan di kota cenderung lebih besar daripada di desa. Hal tersebut disebabkan oleh tingkat kepadatan tempat tinggal, pencemaran udara dan lingkungan di kota yang lebih tinggi daripada di desa (Putra and Wulandari, 2019).

Asrama adalah tempat hunian bersama untuk pelajar yang dibangun dalam berbagai skala, mulai dari skala kecil atau sekitar 50 penghuni hingga skala sangat besar atau sekitar penyediaan lebih dari 200 penghuni. Diberbagai negara, asrama telah dirancang dan dibangun dengan standar-standar khusus sesuai dengan jenjang pendidikan untuk penghuninya. Standar asrama di negara Indonesia telah ditetap kan dengan memperhatikan berbagai faktor seperti kebersihan, keamanan, standar luasan, standar kelengkapan fasilitas dan bahkan standar kebutuhan sosialisasi penghuni (Diningrat Khan and Wulandari, 2017).

Pencemaran udara dalam ruangan salah satunya melibatkan mikroganisme seperti bakteri dan kapang. Kapang adalah fungi multiseluler yang mempunyai filament, dan pertumbuhannya pada substrat mudah dilihat karena penampakannya yang berserabut seperti kapas. Pertumbuhannya mula-mula berwarna putih, tetapi jika spora telah timbul akan terbentuk berbagai warna tergantung dari jenis kapang (Mukono, Prasasti and Sudarmaji, 2005). Pengaruh ruangan yang memiliki kepadatan penghuni dan ruangan yang digunakan bersama memungkinkan ditemukannya kapang udara di dalam ruang. Kapang dikatakan berbahaya jika bersifat patogen dan menghasilkan mikotoksin yang dapat menyebabkan penyakit antara lain iritasi mata, kulit, saluran pernapasan (ISPA) dan lain-lain. Spesies kapang antara lain seperti Cladosporium sp., Penicillium sp., Aspergillus sp., Alternaria sp., Mucor sp., Rhizopus sp. dan Epicoccum sp (Simanjuntak, Khotimah and Linda, 2015).

Pondok Pesantren memiliki kondisi asrama yang padat penghuninya, sehingga mempengaruhi kesehatan santri di pondok pesantren. Berdasarkan penelitian (Sati, Sunarsih and Faisya, 2015), dapat disimpulkan bahwa 71 orang pernah menderita ISPA di Pondok Pesantren Raudhatul Ulum Dan Al-Ittifaqiah Kabupaten Ogan Ilir. Kondisi fisik lingkungan kamar masih kurang memenuhi persyaratan kesehatan. Dilihat dari kepadatan hunian Pondok Pesantren Raudhatul Ulum Dan Al-Ittifaqiah Kabupaten Ogan Ilir tidak sesuai dengan aturan Kemenkes RI No.829/Menkes /SK/VII/1999 yang menyatakan luas ruang tidur minimal $8 \mathrm{~m}$ dan tidak dianjurkan digunakan lebih dari dua orang tidur dalam satu ruang tidur (Sati, Sunarsih and Faisya, 2015).

Data Penelitian lainnya menunjukkan, Pondok Pesantren Raudhatul Ulum Sakatiga di wilayah Kabupaten Ogan Ilir Provinsi Sumatra Selatan penyakit ISPA memiliki posisi urutan pertama yaitu terdapat 178 kasus yang dialami oleh santriwati pada tahun 2014. Pada hari berikutnya terjadi peningkatan penyakit ISPA di Pondok Pesantren AlIttifaqiah di wilayah Kabupaten Ogan Ilir Provinsi Sumatra Selatan yaitu 
sebanyak 231 kasus yang dialami oleh santriwati (Maesaroh, 2018).

Selain ISPA, penyakit lainnya yang sering ditemukan di masyarakat dan disebabkan oleh infeksi jamur adalah gatal pada kulit. Berdasarkan Topografi (bentuk klinis) jamur yang menyerang lapisan luar pada kulit, kuku, dan rambut dibagi dalam 2 bentuk yaitu; Dermatofitosis terdiri dari Tinea Kapitis, Tinea Kruris, Tinea Korporis, Tenia Pedis atau Manus, Tinea Barbae, sedangkan yang tergolong Nondermatofitosis; Tenia Versikolor, Piedra Hitam, Piedra Putih (Siregar, 2012).

Menurut penelitian yang dilakukan oleh (Maesaroh, 2018), Dari survey awal pada bulan januari 2014 terhadap 2 Pondok Pesantren terbesar yaitu Pondok Pesantren Putra "A" dan Pondok Pesantren Putri "P" Di Kabupaten Bekasi bahwa penyakit kulit masih sangat tinggi, menurut Laporan Data Penyakit Pos Kesehatan Pesantren Putra "A" bahwa terjadi 157 kasus penyakit kulit selama tahun 2013 dan menurut Buku Rekapan Data Penyakit Pos Kesehatan Putri "P" bahwa terjadi 122 kasus penyakit kulit selama tahun 2013. Kasus penyakit kulit lebih banyak diderita oleh laki - laki sebesar $55,1 \%$ dibanding perempuan dan personal hygiene memiliki hubungan yang signifikan terhadap kejadian penyakit kulit pada santri Pondok Pesantren Islam.

Personal Hygiene diperlukan dalam kenyamanan individu, keamanan dan kesehatan. Semua itu bentuk upaya untuk meningkatkan kesehatan diri. Kebersihan diri tidak hanya penting bagi kita, namun juga bagi orang di sekitar kita. Oleh karena itu, membersihkan diri menyeluruh sebaiknya tidak terlewatkan mulai dari mencucui pakaian, mandi menggunakan air bersih, ataupun tidak meminjam pakaian orang lain (Fitra and Pranagara, 2018).
Salah satu kebiasaan santri di Pondok Pesantren, yaitu suka meminjam pakaian santri lainnya. Kurangnya pengetahuan tentang personal hygiene inilah yang dapat menimbulkan terjadinya infeksi kapang.

Berdasarkan latar belakang tersebut, maka peneliti melakukan penelitian mengenai cemaran kapang di salah satu pondok pesantren di Surabaya Timur. Peneliti tertarik melakukan penelitian ini karena tingkat santri terkena penyakit ISPA dan gatal pada kulit cukup tinggi sedangkan penelitian tentang cemaran kapang di lingkungan Pondok Pesantren masih sedikit. Sampel penelitiannya yaitu udara pada tiap ruangan yang ada di Pondok Pesantren tersebut dan beberapa sampel baju santri Pondok Pesantren tersebut.Jika memang hasil penelitian menunjukkan ada cemaran kapang di udara pondok pesantren maka peneliti dapat memberikan informasi kepada pihak pondok pesantren, sehingga pihak pondok pesantren dapat memperbaiki sirkulasi udara di tiap ruangan pondok pesantren tersebut.

\section{Metode Penelitian}

Jenis penelitian yang digunakan ini adalah deskriptif dengan tujuan mengidentifikasi dan mengetahui jenis kapang udara yang ada pada ruangan di salah satu Pondok Pesantren di wilayah Surabaya Timur serta baju santri Pondok Pesantren tersebut. Data diperoleh dari hasil pemeriksaan pada sampel udara ruang dan swab baju santri yang dilakukan di Laboratorium Kesehatan Daerah Surabaya.

Pada penelitian ini alat yang digunakan adalah: Neraca analitik, autoclave, pipet tetes, erlenmeyer, beaker glass, gelas ukur, Spatula, Gelas arloji, Petrisidish steril, ose jarum/ kait, obyek glass, cover glass, plastic warp. Pada penelitian ini bahan yang digunakan adalah: media Sabauraud Dextose 
Agar (SDA), KOH 10\%, Alkohol 70\%, api spirtus.

\section{Pembuatan media}

1. Menyiapkan alat dan bahan

2. Melakukan penimbangan media SDA sesuai yang dibutuhkan dengan neraca analitik.

3. Erlenmeyer yang berisi aquadest disiapkan kemudian dimasukkan media SDA kedalam erlenmeyer dan di aduk merata.

4. Dipanaskan sampai mendidih pada Hot plate, kemudian matikan dan melakukan suam-suam kedalam air.

5. Mengukur $\mathrm{pH}$ media hingga sesuai dengan $\mathrm{pH} 5,6 \pm 0,2$. Jika $\mathrm{pH}$ Terlalu tinggi tambahkan HCL. Dan jika terlalu rendah ditamabah $\mathrm{NaOH}$.

6. Media SDA disteril menggunakan Autoclave dengan suhu $121^{\circ} \mathrm{C}$ dan tekanan 1,5 atm selama 15 menit.

7. Dituang kedalam petridisk sebanyak 15 $\mathrm{ml}$, dan tunggu sampai media memadat. Media sudah memadat, media siap untuk digunakan penanaman.

\section{Prosedur pengambilan sampel kapang udara}

1. Menyiapkan alat dan bahan yang akan digunakan.

2. Menaruh petridish yang berisi media SDA pada ruang asrama sesuai dengan kode sampel, sampel diletakkan di tempat atas dan diberi wadah agar tidak terkontaminasi selain kapang udara.

3. Petrisdish yang berisi media SDA dibuka selama 10 menit dengan sudut kemiringan $45^{\circ}$

4. Ditutup kembali petridish secara aseptic dengan cara dipanaskan
5. pinggiran petrisidh (flaming) dan di beri plastik warp.

6. Diinkubasi selama 4 - 5 hari pada suhu ruang $25^{\circ} \mathrm{C}$ dengan posisi terbalik.

\section{Prosedur pengambilan sampel swab pakaian}

1. Sampel pakaian diambil secara acak sejumlah 30 pcs pakaian dari 30 santri yang berbeda.

2. Pakaian dipulaskan (swab) pada area ketiak, kerah, punggung pakaian dengan menggunakan menggunakan kapas lidi steril

3. Kemudian kapas lidi steril yang sudah digunakan pulasan pada pakaian akan digoreskan pada media SDA.

4. Ditutup kembali petridish secara aseptic dengan cara dipanaskan pinggiran petrisidh (flaming) dan di beri plastik warp.

5. Diinkubasi selama 4 - 5 hari pada suhu ruang $25^{\circ} \mathrm{C}$ dengan posisi terbalik.

\section{Prosedur pemeriksaan}

1. Menyiapkan alat dan bahan yang digunakan.

2. Meneteskan reagen $\mathrm{KOH} 10 \%$ pada objek glass yang bersih.

3. Mengambil bagian koloni yang tumbuh dimedia SDA mengunakan ose jarum, kemudian letakkan pada objek glass dan ratakan dengan hatihati.

4. Menutup dengan cover glass, kemudian amati dimikroskop dengan lensa objektif 40X.

\section{HASIL DAN PEMBAHASAN}

Dari hasil pemeriksaan isolasi Kapang udara pada ruang asrama Pondok Pesantren di wilayah Surabaya Timur diperoleh hasil semua media ditumbuhi kapang (100\%). 
Tabel 1.

Hasil Pemeriksaan Kapang Udara Ruangan Asrama Salah Satu Pondok Pesantren di Surabaya Timur

\begin{tabular}{|c|c|c|c|c|}
\hline \multirow[t]{2}{*}{ No } & \multirow[t]{2}{*}{ Kode sampel } & \multirow[t]{2}{*}{ Lokasi isolasi } & \multicolumn{2}{|c|}{ Hasil pemeriksaan } \\
\hline & & & + & - \\
\hline 1 & $\overline{\mathrm{A} 1}$ & KM 1 & $\checkmark$ & $\bar{x}$ \\
\hline 2 & A2 & 2 & $\checkmark$ & $\mathrm{x}$ \\
\hline 3 & A3 & 3 & $\checkmark$ & $\mathrm{x}$ \\
\hline 4 & A4 & 4 & $\checkmark$ & $\mathrm{x}$ \\
\hline 5 & A5 & 5 & $\checkmark$ & $\mathrm{x}$ \\
\hline 6 & A6 & 6 & $\checkmark$ & $\mathrm{x}$ \\
\hline 7 & B1 & KT 1 & $\checkmark$ & $\mathrm{x}$ \\
\hline 8 & B2 & 2 & $\checkmark$ & $\mathrm{x}$ \\
\hline 9 & B3 & 3 & $\checkmark$ & $\mathrm{x}$ \\
\hline 10 & B4 & 4 & $\checkmark$ & $\mathrm{x}$ \\
\hline 11 & B5 & 5 & $\checkmark$ & $\mathrm{x}$ \\
\hline 12 & B6 & 6 & $\checkmark$ & $\mathrm{x}$ \\
\hline 13 & $\mathrm{C} 1$ & RS 1 & $\checkmark$ & $\mathrm{x}$ \\
\hline 14 & $\mathrm{C} 2$ & 2 & $\checkmark$ & $\mathrm{x}$ \\
\hline 15 & C3 & 3 & $\checkmark$ & $\mathrm{x}$ \\
\hline 16 & $\mathrm{C} 4$ & 4 & $\checkmark$ & $\mathrm{x}$ \\
\hline 17 & $\mathrm{C} 5$ & 5 & $\checkmark$ & $\mathrm{x}$ \\
\hline 18 & C6 & 6 & $\checkmark$ & $\mathrm{x}$ \\
\hline 19 & D1 & RT 1 & $\checkmark$ & $\mathrm{x}$ \\
\hline 20 & D2 & 2 & $\checkmark$ & $\mathrm{x}$ \\
\hline 21 & D3 & 3 & $\checkmark$ & $x$ \\
\hline 22 & D4 & 4 & $\checkmark$ & $\mathrm{X}$ \\
\hline 23 & D5 & 5 & $\checkmark$ & $\mathrm{X}$ \\
\hline 24 & D6 & 6 & $\checkmark$ & $\mathrm{X}$ \\
\hline 25 & E1 & RJ 1 & $\checkmark$ & $\mathrm{X}$ \\
\hline 26 & E2 & 2 & $\checkmark$ & $\mathrm{X}$ \\
\hline 27 & E3 & 3 & $\checkmark$ & $\mathrm{X}$ \\
\hline 28 & E4 & 4 & $\checkmark$ & $\mathrm{X}$ \\
\hline 29 & E5 & 5 & $\checkmark$ & $\mathrm{X}$ \\
\hline 30 & E6 & 6 & $\checkmark$ & $\mathrm{x}$ \\
\hline
\end{tabular}

Keterangan :

KM : Kamar Mandi

KT : Kamar Tidur

RS : Ruang Sekertariat

RT : Ruang Tamu

RJ : Ruang Jemur 


\section{Pengamatan hasil inkubasi media SDA}

Setelah media SDA diinkubasi selama 5 hari pada suhu ruang, media SDA dikeluarkan dan dilakukan pengamatan secara makroskopis sebagai berikut : Positif (+) : Ditemukan koloni kapang, berupa hifa yang seperti kapas/ bludru. Negative (-) : jika tidak ditemukan koloni kapang, berupa hifa seperti kapas/ bludru.

Pada Tabel 1, menunjukkan bahwa semua media SDA yang digunakan untuk sampling udara pada beberapa ruangan di salah satu Pondok Pesantren Surabaya Timur ditumbuhi koloni kapang. Ciri - riri dari koloni kapang yaitu terdapat kumpulan hifa atau miselium yang teksturnya seperti kapas atau bludru, warna dasar koloni kuning sampai hijau kecoklatan sedangkan warna koloni putih, hitam, dan hijau (Gambar 1.). Hasil positif selanjutnya diamati morfologi secara mikroskopis untuk masing-masing koloni. Berikut hasil dari pemeriksaan isolat dari beberapa sampel: ada Tabel 1, menunjukkan bahwa semua media SDA yang digunakan untuk sampling udara pada beberapa ruangan di salah satu Pondok Pesantren Surabaya Timur ditumbuhi koloni kapang. Ciri - riri dari koloni kapang yaitu terdapat kumpulan hifa atau miselium yang teksturnya seperti kapas atau bludru, warna dasar koloni kuning sampai hijau kecoklatan sedangkan warna koloni putih, hitam, dan hijau (Gambar 1.). Hasil positif selanjutnya diamati morfologi secara mikroskopis untuk masing-masing koloni. Berikut hasil dari pemeriksaan isolat dari beberapa sampel:

\section{Gambar 1}

Hasil Pertumbuhan Kapang Pada Media SDA Hasil Isolasi Udara Pada Salah Satu Pondok Pesantren Surabaya Timur

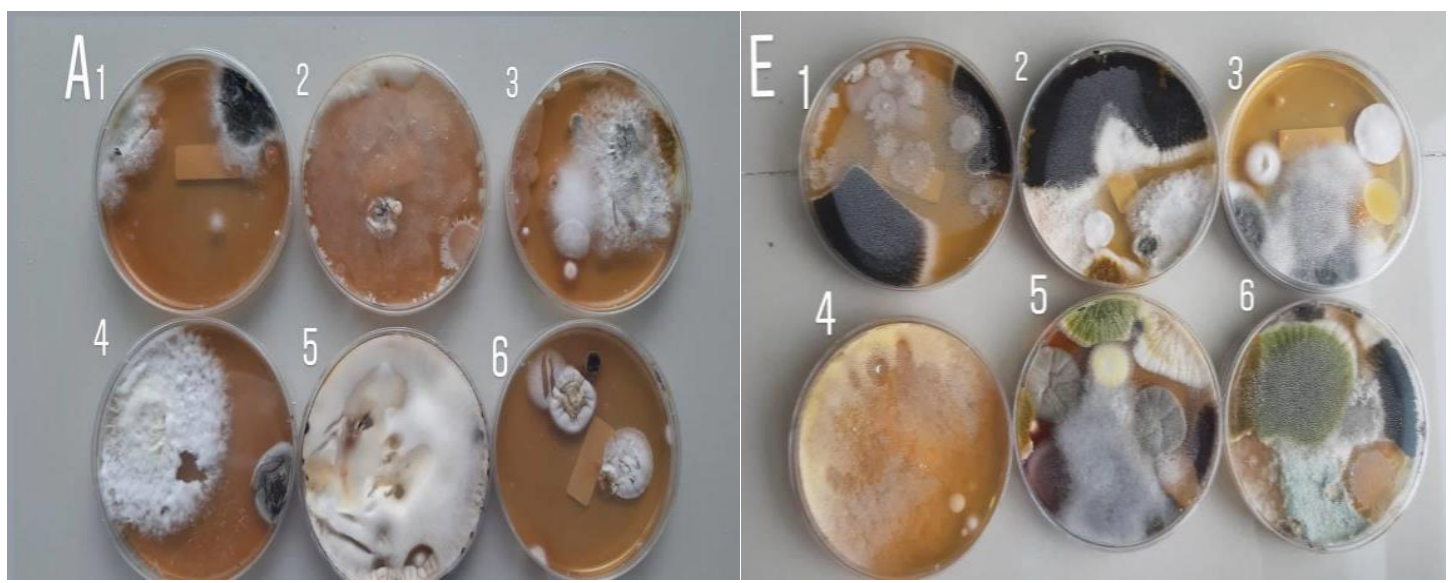

\section{Gambar 2}

Hasil Pengamatan Mikroskopis Hasil Isolasi Udara Pada Salah Satu Pondok Pesantren Surabaya Timur

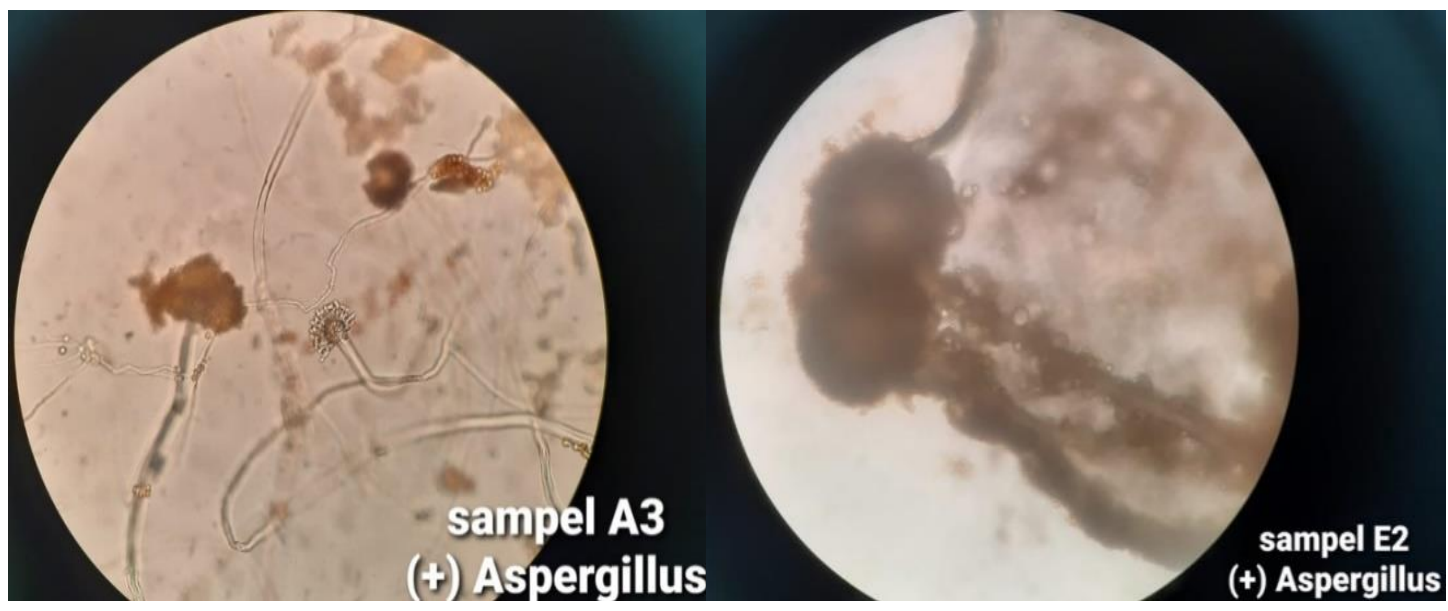

70 | Volume 4, No 1 (2021) 
Pada pemeriksaan secara mikroskopis, setiap koloni diambil untuk diamati morfologinya. Hasil yang didapat semua koloni merupakan kapang jenis Aspergillus spp. (Gambar 2.). Genus Aspergillus merupakan kapang dengan ciri - ciri : Hifa septat dan miselium bercabang, biasanya tidak berwarna, yang terdapat dibawah permukaan merupakan hifa vegetatif, sedangkan yang muncul diatas permukaan adalah hifa fertile, koloni berkelompok, konidia membentuk rantai yang berwarna hijau, cokelat, atau hitam, beberapa spesies tumbuh baik pada suhu $37 \circ$ C atau lebih (Sastrahidayat, 2011).

Berdasarkan hasil penelitian dan pengamatan secara langsung yang dilakukan oleh peneliti membuktikan bahwa hampir semua ruangan kondisinya lembab juga minimnya ventilasi dan sinar matahari bisa masuk. Rata-rata penghuni asrama belum mengetahui bahwa pentingnya menjaga kebersihan tempat tinggal, serta memberikan sirkulasi udara yang cukup dan memberikan cahaya matahari yang maksimal dengan cara membuka jendela, membersihkan pakaian yang berserakan atau tidak dipakai kembali agar tidak dapat menyebabkan kelembapan disuatu ruangan tersebut yang berpotensi timbulnya Kapang udara.

Jenis Kapang udara pada hasil identifikasi sampel ruang asrama di pondok pesantren ini yaitu Kapang Aspergillus sp. Aspergillus sp. merupakan salah salah satu kapang yang berasal dari class Ascomycota. Aspergillus adalah spesies yang telah menyebar luas, karena spora jamur yang mudah disebarkan oleh angin (Praja and Yudhana, 2018). Aspergillus merupakan jamur yang mampu hidup pada medium dengan derajat keasaman dan kandungan gula yang tinggi. Aspergillus ada yang bersifat parasit, ada pula yang besifat saprofit. Aspergillus yang bersifat parasit menyebabkan penyakit Aspergillosis (Gandi, Getas and Jannah, 2019). Aspergillus sp. sering ditemukan pada bahan pakan yang disimpan di dalam gudang dengan kelembaban tinggi. Aspergillus sp. dianggap patogen karena dapat menyebabkan suatu penyakit saluran pernafasan, radang granulomatosis pada selaput lendir, mata, telinga, kulit, meningen, bronchus dan paru-paru (Hayani, Erina and Darniati, 2017).

Sedangkan untuk hasil pemeriksaan swab baju santri Pondok Pesantren ini didapatkan hasil sebagai berikut:

\section{Gambar 3}

Hasil Pertumbuhan Kapang pada Media SDA Hasil Swab Pakaian Santri Salah Satu Pondok Pesantren Surabaya Timur

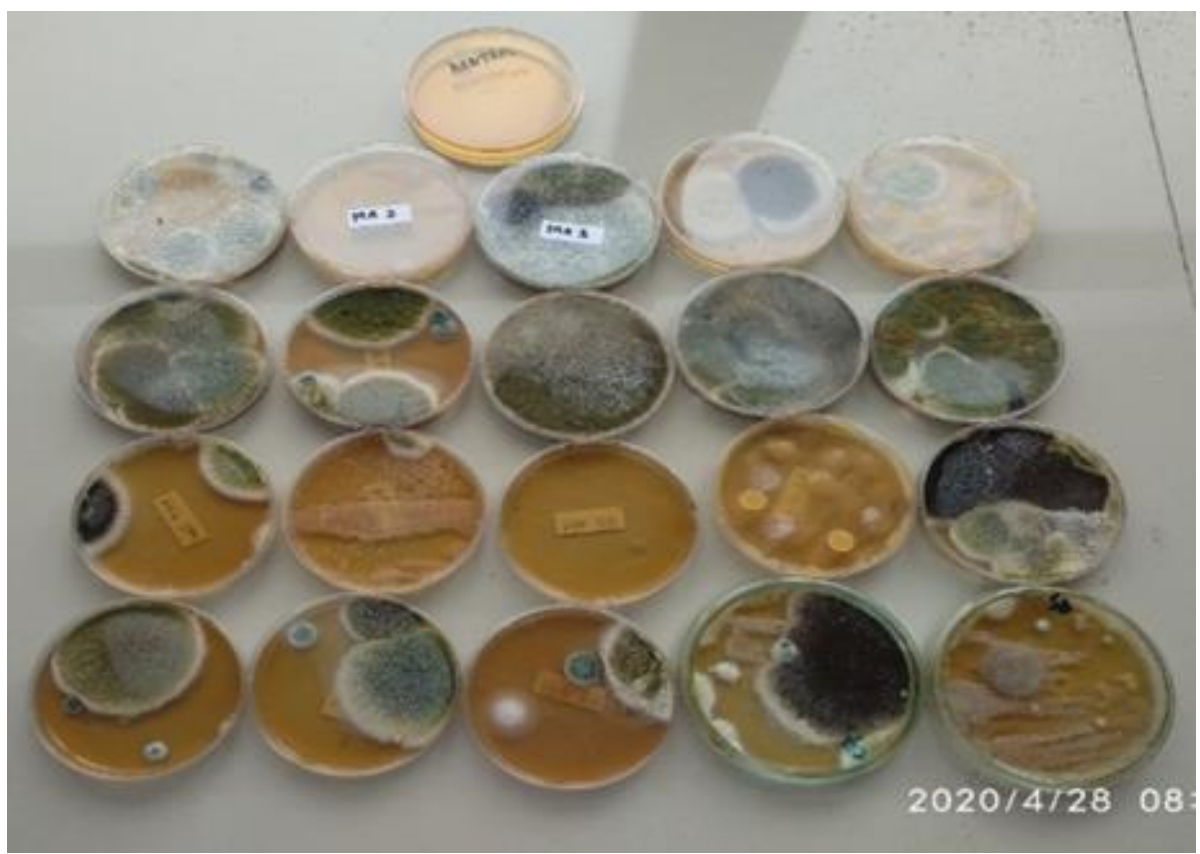




\section{Tabel 2}

Hasil Pemeriksaan Swab Baju Santri Salah Satu Pondok Pesantren di Surabaya Timur.

\begin{tabular}{|c|c|c|c|}
\hline \multirow[t]{2}{*}{ No } & \multirow[t]{2}{*}{ Kode Sampel } & \multicolumn{2}{|c|}{ Hasil Identifikasi } \\
\hline & & Positif & Negatif \\
\hline 1 & MA 1 & + & \\
\hline 2 & MA 2 & & - \\
\hline 3 & MA 3 & + & \\
\hline 4 & MA 4 & + & \\
\hline 5 & MA 5 & + & \\
\hline 6 & MA 6 & + & \\
\hline 7 & MA 7 & + & \\
\hline 8 & MA 8 & + & \\
\hline 9 & MA 9 & + & \\
\hline 10 & MA 10 & + & \\
\hline 11 & MA 11 & + & \\
\hline 12 & MA 12 & + & \\
\hline 13 & MA 13 & + & \\
\hline 14 & MA 14 & + & \\
\hline 15 & MA 15 & & - \\
\hline 16 & MA 16 & & - \\
\hline 17 & MA 17 & + & \\
\hline 18 & MA 18 & + & \\
\hline 19 & MA 19 & + & \\
\hline 20 & MA 20 & + & \\
\hline 21 & MA 21 & + & \\
\hline 22 & MA 22 & & - \\
\hline 23 & MA 23 & + & \\
\hline 24 & MA 24 & + & \\
\hline 25 & MA 25 & + & \\
\hline 26 & MA 26 & + & \\
\hline 27 & MA 27 & & - \\
\hline 28 & MA 28 & & - \\
\hline 29 & MA 29 & + & \\
\hline 30 & MA 30 & + & \\
\hline
\end{tabular}

\section{Gambar 4}

Hasil Pengamatan Mikroskopis Hasil Swab Pakaian Pada Salah Satu Pondok Pesantren Surabaya Timur

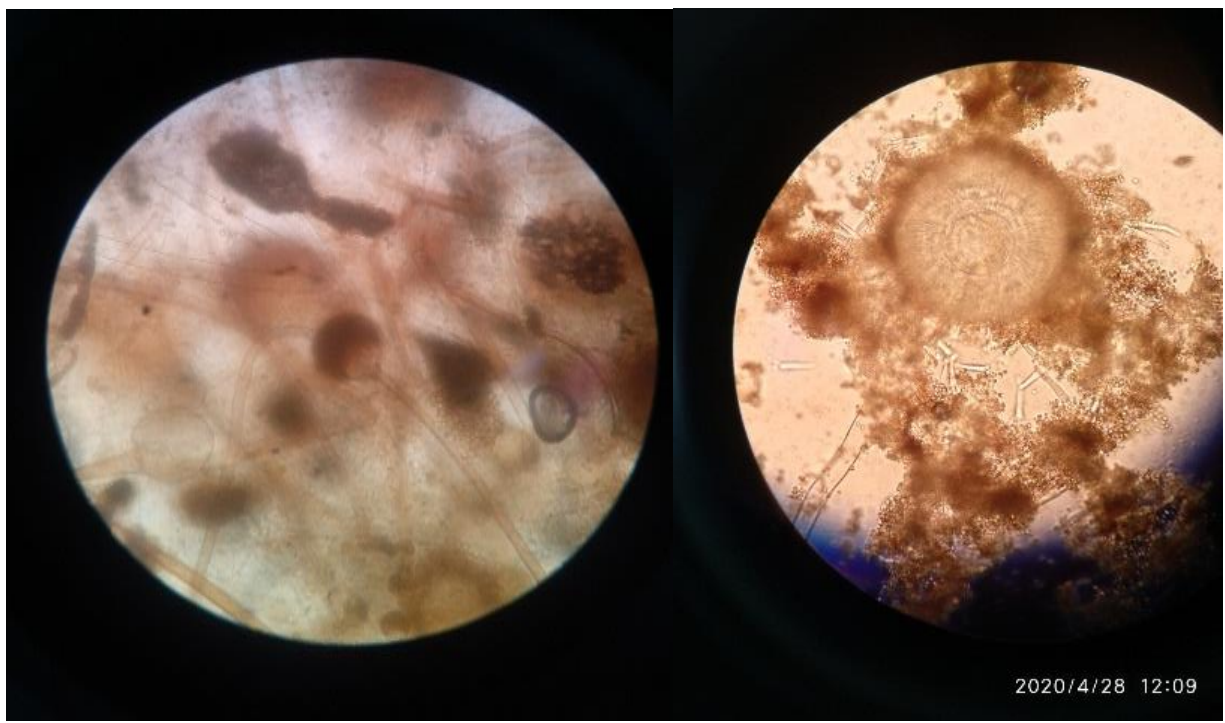

72 | Volume 4, No 1 (2021) 
Hasil pemeriksaan jamur kapang pada pakaian santri salah satu Pondok Pesantren di Surabaya Timur, secara makroskopis yang dilakukan, ditemukan pertumbuhan jamur kapang yang berbentuk seperti bludru yang berwarna keputihan dengan miselium berwarna hitam, hijau, kekuningan pada media Saboruth Dextrose Agar (Gambar 3.). Dari 30 sampel pakaian yang diambil secara acak, diperoleh hasil positif $80 \%$ terkontaminasi kapang dan negatif $20 \%$ tidak terdapat kontaminasi kapang (Tabel 2.).

Dari hasil pengamatan secara makroskopis, terlihat bahwa pada media SDA dari hasil swab pakaian santri, 24 media tumbuh koloni kapang berwarna hitam, putih, sampai hijau kekuningan. Koloni yang berbeda-beda warna diambil kemudian diperiksa dibawah mikroskop. Dari hasil pengamatan mikroskopis, didapatkan bahwa baik koloni yang berwarna hitam, putih, dan hijau kekuningan adalah jamur Aspergillus sp.

Hasil tersebut dapat dipengaruhi oleh beberapa faktor, diantaranya penanganan pada pakaian yang kurang baik, mencucinya kurang bersih, menjemurnya kurang kering atau kurang tepat sehingga terjadinya kontaminasi pada pakaian santri, dan dapat mengakibatkan iritasi pada tubuh santri seperti gatal-gatal ataupun berjamur pada kulit santri sehingga pakaian yang dipakai oleh santri tidak nyaman untuk digunakan.

Sedangkan hasil yang tidak ditumbuhi kapang sebesar 20\% dipengaruhi oleh faktor, santri melakukan penanganan pakaian dengan baik dengan cara mencuci bersih pakaian, menjemur dibawah terik matahari, mensetrika pakaian, dan menyimpannya secara rapi di dalam lemari. Sehingga pakaian yang dipakai oleh santri nyaman dipakai, bersih dan rapi.
Hasil pengamatan yang dilakukan oleh peniliti, bahwa kebanyakan pakaian santri di pondok pesantren ini dalam sistem penyimpanannya yang dilakukan oleh santri umumnya diletakkan di ruang terbuka dan suhu ruangan yang akan mengakibatkan terjadinya kontaminasi jamur pada pakaian santri tersebut dan bisa juga karena faktor santri yang sering gonta-ganti pakaian dengan cara meminjam pakaian ke teman santrinya untuk dipakai sehingga akan mengakibatkan kontaminsi silang, yang akan mengakibatkan iritasi pada kulit santri ataupun gatal-gatal dan tidak nyaman untuk digunakan.

\section{Simpulan}

Berdasarkan hasil penelitian, semua ruangan yang ada di salah satu Pondok Pesantren di Surabaya Timur ini tercemar kapang udara dan hasil swab sampel pakaian santri Pondok Pesantren ini 80\% terkontaminasi jamur Aspergillus sp. dan $20 \%$ tidak tercemar.

\section{Daftar Pustaka}

Diningrat Khan, R. and Wulandari, R. (2017) 'Studi Komparasi Fasilitas Dan Standar Asrama Di Indonesia: Studi Kasus 5 Universitas', Idealog: Ide dan Dialog Desain Indonesia, 1(2), p. 193. doi: 10.25124/idealog.v1i2.852.

Fitra, M. and Pranagara, R. (2018) 'Hubungan Antara Personal Hygiene Dengan Kejadian Skabies Pada Santri Di Pondok Pesantren Al-Amalul Khair Kota Palembang 2018'.

Gandi, N. L. G., Getas, I. W. and Jannah, M. (2019) 'Studi Jamur Aspergillus fumigatus penyebab Aspergillosis di Pasar Cakranegara Kota Mataram dengan Media Pertumbuhan Potato Dextrose Agar (PDA)', Jurnal Analis Medika Biosains (JAMBS), 6(1), p. 81. doi: 10.32807/jambs.v6i1.128. 
Hayani, N., Erina and Darniati (2017) 'Isolasi Aspergillus sp Pada Paru-Paru Ayam Kampung ( Gallus domesticus )', Jimvet, 01(4), pp. 637-643.

Maesaroh, S. (2018) 'Hubungan pengetahuan tentang personal hygiene dengan kejadian penyakit kulit di Pondok Pesantren Butanul Ulum Sridadi Kalirejo Kabupaten Lampung Tengah', Jurnal Aisyah: Jurnal Ilmu Kesehatan, 3(2), pp. 183-190.

Mukono, J., Prasasti, C. and Sudarmaji, S. (2005) 'Pengaruh Kualitas Udara dalam Ruangan Ber-ac terhadap Gangguan Kesehatan', Jurnal Kesehatan Lingkungan Unair, 1(2), p. 3941.

Praja, R. N. and Yudhana, A. (2018) 'Isolasi Dan Identifikasi Aspergillus Spp pada Paru-Paru Ayam Kampung Yang Dijual di Pasar Banyuwangi', Jurnal Medik Veteriner, 1(1), p. 6. doi: 10.20473/jmv.vol1.iss1.2017.6-11.

Putra, Y. and Wulandari, S. S. (2019) 'Faktor Penyebab Kejadian Ispa', Jurnal Kesehatan, 10(1), p. 37. doi: 10.35730/jk.v10i1.378.

Sastrahidayat, I. R. (2011) Mikologi (Ilmu Jamur). 1st edn. Malang: Universitas Brawijaya Press. Available at: https://books.google.co.id/books/abo ut/Mikologi_Ilmu_Jamur.html?id=AO mZDwAAQBAJ\&printsec $=$ frontcover\& source=kp_read_button\&redir_esc=y\# $\mathrm{v}=$ onepage \&q\&f=false.

Sati, L., Sunarsih, E. and Faisya, A. (2015) 'HUBUNGAN Kualitas Udara Dalam Ruangan Asrama Santriwati Dengan Kejadian Ispa Di Pondok Pesantren Raudhatul Ulum Dan Al-Ittifaqiah Kabupaten Ogan Ilir Tahun 2015', Jurnal Ilmu Kesehatan Masyarakat, 6(2), pp. 121-133.

Simanjuntak, N., Khotimah, S. and Linda, R. (2015) 'Keanekaragaman Kapang Udara di Ruang Perkuliahan Fakultas Matematika dan Ilmu Pengetahuan Alam Universitas Tanjungpura Pontianak', Jurnal Protobiont, 4(2), pp. 55-62.

Siregar, R. (2012) Penyakit Jamur Kulit Ed.2. 2nd edn. Jakarta: EGC. 